\title{
Thiamine supplementation facilitates thiamine transporter expression in the rumen epithelium and attenuates high-grain-induced inflammation in low-yielding dairy cows
}

\author{
X. H. Pan, ${ }^{*}$ L. Yang, ${ }^{*}$ Y. Beckers, † F. G. Xue, ${ }^{*}$ Z. W. Tang, ${ }^{*}$ L. S. Jiang, $\ddagger^{1}$ and B. H. Xiong ${ }^{* 1}$ \\ *State Key Laboratory of Animal Nutrition, Institute of Animal Science, Chinese Academy of Agricultural Sciences, Beijing, 100193, P. R. China \\ †Gembloux Agro-Bio Tech, Precision Livestock and Nutrition, University of Liège, Passage des Déportés 2, B-5030 Gembloux, Belgium \\ ‡Beijing Key Laboratory for Dairy Cow Nutrition, Beijing University of Agriculture, Beijing, 102206, P. R. China
}

\begin{abstract}
An experiment was conducted to uncover the effects of increasing dietary grain levels on expression of thiamine transporters in ruminal epithelium, and to assess the protective effects of thiamine against highgrain-induced inflammation in dairy cows. Six rumenfistulated, lactating Holstein dairy cows $(627 \pm 16.9 \mathrm{~kg}$ of body weight, $180 \pm 6 \mathrm{~d}$ in milk; mean \pm standard deviation) were randomly assigned to a replicated 3 $\times 3$ Latin square design trial. Three treatments were control (20\% dietary starch, dry matter basis), highgrain diet (HG, 33.2\% dietary starch, DM basis), and HG diet supplemented with $180 \mathrm{mg}$ of thiamine/ $\mathrm{kg}$ of dry matter intake. On d 19 and 20 of each period, milk performance was measured. On d 21, ruminal $\mathrm{pH}$, endotoxic lipopolysaccharide (LPS), and thiamine contents in rumen and blood, and plasma inflammatory cytokines were detected; a rumen papillae biopsy was taken on d 21 to determine the gene and protein expression of toll-like receptor 4 (TLR4) signaling pathways. The HG diet decreased ruminal $\mathrm{pH}$ (5.93 vs. 6.49), increased milk yield from 17.9 to $20.2 \mathrm{~kg} / \mathrm{d}$, and lowered milk fat and protein from 4.28 to $3.83 \%$, and from 3.38 to $3.11 \%$, respectively. The HG feeding reduced thiamine content in rumen $(2.89$ vs. $8.97 \mu \mathrm{g} / \mathrm{L})$ and blood $(11.66$ vs. $17.63 \mu \mathrm{g} / \mathrm{L})$, and the relative expression value of thiamine transporter-2 (0.37-fold) and mitochondrial thiamine pyrophosphate transporter $(0.33$-fold $)$ was downregulated by HG feeding. The HG-fed cows exhibited higher endotoxin LPS in rumen fluid $(134,380$ vs. 11,815 endotoxin units $/ \mathrm{mL}$ ), and higher plasma concentrations of lipopolysaccharide binding protein and pro-inflammatory cytokines when compared with the control group. The gene and protein expression of tumor necrosis factor $\alpha(\mathrm{TNF} \alpha)$, IL1B, and IL6 in
\end{abstract}

Received September 7, 2016.

Accepted January 30, 2017.

${ }^{1}$ Corresponding authors: xiongbenhai@caas.cn and jls@bac.edu.cn rumen epithelium increased when cows were fed the HG diet, indicating that local inflammation occurred. The depressions in ruminal $\mathrm{pH}$, milk fat, and protein of HG-fed cows were reversed by thiamine supplementation. Thiamine supplementation increased thiamine contents in rumen and blood, and also upregulated the relative expression of thiamine transporters compared with the HG group. Thiamine supplementation decreased ruminal LPS (49,361 vs. 134,380 endotoxin units $/ \mathrm{mL}$ ) and attenuated the HG-induced inflammation response as indicated by a reduction in plasma IL6, and decreasing gene and protein expression of proinflammatory cytokines in rumen epithelium. Western bottling analysis showed that thiamine suppressed the protein expression of TLR4 and the phosphorylation of nuclear factor kappa B (NFkB) unit p65. In conclusion, HG feeding inhibits thiamine transporter expression in ruminal epithelium. Thiamine could attenuate the epithelial inflammation during high-grain feeding, and the protective effects may be due to its ability to suppress TLR4-mediated NFKB signaling pathways.

Key words: thiamine, high-grain feeding, transporter, inflammation, nuclear factor kappa B

\section{INTRODUCTION}

Dairy cows are often fed high-grain diets to maximize energy intake and to support high milk production. However, overfeeding cows with grain-rich diets results in several disorders such as SARA and liver abscesses (Emmanuel et al., 2008). Feeding high amounts of rapidly fermenting carbohydrates decreased rumen $\mathrm{pH}$, altered rumen microbial population, and increased concentrations of endotoxin (LPS) in rumen fluid (Khafipour et al., 2009; Plaizier et al., 2014). The altered ruminal LPS and $\mathrm{pH}$ could act synergistically to disrupt barrier function (Emmanuel et al., 2007), and once the epithelium has been breached, mucosa-associated lymphoid tissue cells respond by triggering local inflammation via LPS/toll-like receptor 4 (TLR4) signaling 
pathway, and the pro-inflammatory cytokines would be excessively produced (Kurashima et al., 2013; Zhang et al., 2016). Moreover, the impaired barrier function of gastrointestinal epithelium facilitates the translocation of LPS from the digestive tract into the circulation, and may trigger systemic inflammation by promoting the release of pro-inflammatory cytokines (Dong et al., 2013).

Thiamine plays a critical role in carbohydrate metabolism and is essential for normal cellular functions and growth. Breves et al. (1981) and Miller et al. (1986) reported that ruminants have no dietary thiamine requirements because of the ability of the rumen microbes to synthesize thiamine. However, Dabak and Gul (2004), Karapinar et al. (2010), and Pan et al. (2016) found that thiamine deficiency occurred when sheep or cattle had subacute or acute ruminal acidosis, and it is associated with the increasing thiamine degradation by thiaminase and the decreasing microbial thiamine synthesis activity under high-grain-induced SARA (Brent, 1976). Our previous study found that thiamine supplementation in high-grain diet could increase ruminal $\mathrm{pH}$ and decrease rumen lactate concentration (Pan et al., 2016), and thiamine regulated the structure of rumen microbial community of SARA cows by reducing the population of Streptococcus bovis and prompting the growth of Megasphaera elsdenii (Wang et al., 2015).

In our previous study (Pan et al., 2016), SARA induced by a high-grain diet decreased the blood thiamine contents, and we attributed it to the low ruminal contents and abnormal absorption from the gastrointestinal tract. It is widely accepted that thiamine absorbed in the intestine, but whether rumen wall is permeable to thiamine has remained controversial. Hoeller et al. (1977) and Garnsworthy (2013) found that rumen wall mucosa has low permeability to thiamine. However, McDowell (2012) reported that the rumen wall is just not permeable for bound thiamine or for thiamine contained in rumen microorganisms, but ruminants can absorb free thiamine from the rumen by active transport mechanism. The active absorption of thiamine is mediated by transporter-1 and transporter-2 (THTR1 and THTR2), which are coded by SLC19A2 and SLC19A3, respectively (Zhao and Goldman, 2013; Zhu et al., 2015). In recent human research, Ganapathy et al. (2004) demonstrated that SLC19A2 and SLC19A3 are expressed ubiquitously, and thiamine influx into cells via THTR1 and THTR2 is enhanced by an outwardly directed $\mathrm{H}^{+}$gradient $\left(\mathrm{pH}_{\text {out }}>\mathrm{pH}_{\mathrm{in}}\right)$. Under high-grain feeding, the accumulation of acids would decrease the outwardly directed $\mathrm{H}^{+}$gradient and may influence the ruminal epithelium uptake of free thiamine. The first hypothesis of our study is that thiamine absorption in rumen epithelium can be blocked by high-grain feeding.
In addition to carbohydrate metabolism, thiamine holds a key position in regulation of oxidative stress, excitotoxicity, and inflammation (Hazell and Butterworth, 2009). Thiamine deficiency prompts the release of pro-inflammatory cytokines via regulation of nuclear factor kappa B (NF $\mathbf{B} \mathbf{B})$ signaling pathways (Jhala et al., 2014). Investigations from human and rat have indicated that thiamine administration has a positive effect on inflammation and immune response (Gonzalez-Ortiz et al., 2011; Shoeb and Ramana, 2012). Yadav et al. (2010) and Bozic et al. (2015) found that benfotiamine, a fat-soluble vitamin $\mathrm{B}_{1}$ analog, could modulate the macrophage inflammatory response against LPSinduced inflammation by inhibiting translocation of NF $\kappa B$ p65 into the nucleus. However, to our knowledge, research about anti-inflammation of thiamine in dairy cows has not been conducted. The second objective of this study is to evaluate the anti-inflammatory properties of thiamine supplementation in high-grain-fed dairy cows.

\section{MATERIALS AND METHODS}

\section{Animals and Experimental Design}

Animal care and procedures were in accordance with the Chinese guidelines for animal welfare and approved by Animal Care and Use Committee of the Chinese Academy of Agricultural Sciences. Six Chinese Holstein dairy cows in second parity fitted with $10-\mathrm{cm}$ ruminal cannulas (Bar Diamond, Parma, ID) were allocated to a replicated $3 \times 3$ Latin square design. Cows had an average milk yield of $24.4 \pm 3.1 \mathrm{~kg} / \mathrm{d}$ and $180 \pm 6$ DIM (mean $\pm \mathrm{SD}$ ), and an average BW of $627 \pm 16.9 \mathrm{~kg}$ (mean $\pm \mathrm{SD}$ ) at the beginning of the experiment. They were paired according to initial weight, DIM, and milk production. The 3 periods consisted of a 18-d adaptation period, followed by a 3 -d period used for data and sample collection. Treatments included a control diet (CON; $20 \%$ starch, DM basis), high-grain diet (HG, $33.2 \%$ starch, DM basis), and HG diet supplemented with $180 \mathrm{mg}$ of thiamine/kg of DMI $(\mathbf{H G}+\mathbf{T})$. This dose of thiamine was selected based on our previous dose-response studies in dairy cows (Zhang et al., 2014; Wang et al., 2015). Thiamine (Thiamine hydrochloride, purity $\geq 99 \%$; Wanrong Science and Technology Development Co. Ltd., Wuhan, China) was administered via the ruminal cannula twice daily after supplying diets.

\section{Experimental Diets and Feeding}

The diets were formulated according to NRC (2001) to meet or exceed the energy requirements of Holstein dairy cows yielding $20 \mathrm{~kg}$ of milk/d with $3.5 \%$ milk 
fat and $3.0 \%$ milk protein. Diet composition and its chemical analysis are shown in Table 1. Experimental animals were fed a TMR ad libitum twice daily at 0600 and $1800 \mathrm{~h}$. The TMR samples and orts were collected daily, stored at $-20^{\circ} \mathrm{C}$, and pooled weekly for analyses. The DM was determined by oven drying at $105^{\circ} \mathrm{C}$ until constant weight (AOAC method 930.15, AOAC International, 1995). The CP content was measured by Kjeldahl nitrogen analysis (AOAC method 954.01, AOAC International, 1995). Ether extract was determined using a Soxhlet apparatus (AOAC method 945.16, AOAC International, 1995). Contents of NDF and ADF were determined according to the procedure of Van Soest et al. (1991) using heat-stable amylase (Sigma no. A3306, Sigma Chemical Co., St. Louis, MO) and sodium sulfite, and expressed without residual ash. The total ash content was determined using AOAC method 942.05 (AOAC, 1990). Dietary calcium and phosphorus contents were analyzed using colorimetric method according to the Chinese National Standard GB/T 6436-2002 and GB/T 6437-2002, respectively (Department of National Standards of P. R. China, 2002a,b). The starch in the sample was determined by an enzymatic method $(\alpha$-amylase and amyloglucosidase) using a commercial starch analysis kit (Megazyme International Ireland Ltd., Bray Co., Ireland). The thiamine in feeds was extracted and determined by HPLC method according to the Chinese National Standard (GB/T 14700-2002; Department of National Standards of P. R. China, 2002c) and Analytical Methods Committee (2000). In brief, standard curves were prepared as followed: a standard stock solution was prepared by dissolving 0.05 $\mathrm{g}$ of thiamine hydrochloride (Sigma-Aldrich, Oakville, ON, Canada) in a final volume of $100 \mathrm{~mL}$ of $0.01 \mathrm{M}$ $\mathrm{HCl}$ solution (Sigma-Aldrich). Then, $2 \mathrm{~mL}$ of the solution was diluted in $98 \mathrm{~mL}$ of ultrapure water to obtain an initial concentration of $10 \mu \mathrm{g} / \mathrm{mL}$ of thiamine, which was used to obtain a 5-level standard curve (0.05-1.0 $\mu \mathrm{g} / \mathrm{mL}$ ). To extract thiamine in the diet, $2 \mathrm{~g}$ of feed sample and $60 \mathrm{~mL}$ of $0.1 \mathrm{M} \mathrm{HCl}$ were mixed in a 100 $\mathrm{mL}$ amber Erlenmeyer flask and heated in a boiling water bath $\left(100^{\circ} \mathrm{C}, 30 \mathrm{~min}\right)$. After the mixture cooled down, pH was adjusted to 4.0 to 4.5 with $2.0 \mathrm{M}$ sodium acetate (Sigma-Aldrich). One milliliter of an aqueous trienzyme mix was added, containing papain (60 U, Sigma-Aldrich), $\alpha$-amylase (10,167 U, Sigma-Aldrich), and acid phosphatase (14 U, Sigma-Aldrich). The samples were mixed and incubated for $16 \mathrm{~h}$ at $37^{\circ} \mathrm{C}$, and then heated to inactivate the enzymes $\left(100^{\circ} \mathrm{C}\right.$, $5 \mathrm{~min}$ ). After cooling to room temperature, samples were diluted to $100 \mathrm{~mL}$ with deionized water and then filtered and stored under $-20^{\circ} \mathrm{C}$ until analysis. The 1 $\mathrm{mL}$ of filtrate was shaken thoroughly with $500 \mu \mathrm{L}$ of oxidative solution $(5 \mathrm{~mL}$ of $2 \%$ potassium ferricyanide mixed with $200 \mathrm{~mL}$ of $10 \%$ sodium hydroxide) for 5 min, and then $1 \mathrm{~mL}$ of 2-butanol was added and mixed again. The butanol phase was removed to tubes and centrifuged at $12,000 \times g$ at $4^{\circ} \mathrm{C}$ for $5 \mathrm{~min}$. The 20 $\mu \mathrm{L}$ of supernatant was injected into the HPLC. The analysis was carried out on a Shim-pack VP-ODS C18 column $(250 \times 4.6 \mathrm{~mm}, 5 \mu \mathrm{m}$; Shimadzu Co., Kyoto, Japan). The mobile phase was composed of $650 \mathrm{~mL}$ of $0.05 M$ sodium acetate buffer $(\mathrm{pH}=4.5)$ and $350 \mathrm{~mL}$ of methanol at a flow rate of $1.0 \mathrm{~mL} / \mathrm{min}$, with the fluorimetric detection system adjusted at 435 and 375 $\mathrm{nm}$ for emission and excitation, respectively.

\section{Milk Sampling and Analysis}

Cows were milked at 0800 and $1900 \mathrm{~h}$ daily. The milk production was recorded and milk samples were collected on d 19 and 20 of each period. Daily samples were mixed with a ratio of $6: 4$ and analyzed for milk fat, protein, and lactose contents by mid-infrared spectroscopy (Fossomatic 4000, Foss Electric A/S, Hillerød, Denmark). Milk fat and protein yields were calculated from milk yield and milk fat and protein contents.

\section{Ruminal Fluid Sampling and Analysis}

On d 21 of each period, rumen contents were collected from cranial, caudal, dorsal, and ventral aspects of the rumen, and $\mathrm{pH}$ was determined every $1.5 \mathrm{~h}$ from 0 to $12 \mathrm{~h}$ after morning feeding. Rumen contents sampled at $3 \mathrm{~h}$ postfeeding were strained through 4 layers of cheesecloth with a mesh size of $250 \mu \mathrm{m}$. The $20 \mathrm{~mL}$ of rumen fluid was centrifuged $\left(1,854 \times g, 4^{\circ} \mathrm{C}\right)$ for $10 \mathrm{~min}$ to remove the feed particles. The $1 \mathrm{~mL}$ of sulfuric acid solution $(1.0 \mathrm{M})$ was added to $9 \mathrm{~mL}$ of supernatant, and samples were then frozen at $-20^{\circ} \mathrm{C}$ for thiamine analysis. For thiamine analysis, the $1 \mathrm{~mL}$ of rumen fluid was mixed with $500 \mu \mathrm{L}$ of oxidative solution and then determined by HPLC method as mentioned in thiamine determination of feedstuff.

Another portion of $25-\mathrm{mL}$ rumen fluid samples was transferred into sterilized centrifuge tubes and centrifuged for $30 \mathrm{~min}$ at $10,000 \times g$ at $4^{\circ} \mathrm{C}$. The supernatant was passed through a disposable $0.22-\mu \mathrm{m}$ sterile, pyrogen-free filter (Millex; Millipore Corporation, Bedford, $\mathrm{MA}$ ). Samples were further heated at $100^{\circ} \mathrm{C}$ for $30 \mathrm{~min}$ before being stored at $-20^{\circ} \mathrm{C}$ for LPS determination. Concentrations of free LPS in the rumen fluid were determined using the Chromogenic End-point Tachypleus Amebocyte Lysate Assay Kit (Chinese Horseshoe Crab Reagent Manufactory Co. Ltd., Xiamen, China) with a minimum detection limit of 0.1 endotoxin unit (EU)/ $\mathrm{mL}$. Samples were diluted using pyrogen-free water and pyrogen-free test tubes until their LPS concentrations 
were in the range of 0.1 to $1 \mathrm{EU} / \mathrm{mL}$ relative to the reference endotoxin (Escherichia coli O111:B4). The optical density at $545 \mathrm{~nm}$ was measured on the microplate reader (Multiskan MK3, Thermo Labsystems, Philadelphia, PA).

\section{Blood Sampling and Analysis}

Approximately $3 \mathrm{~h}$ after morning feeding on $\mathrm{d} 21$ of each period, coccygeal blood samples were taken and collected into 10-mL evacuated tubes coated with freeze-dried sodium heparin (Kindly Enterprise Development Group Co. Ltd., Shanghai, China). Samples were immediately kept on ice until being centrifuged at $3,000 \times g$ for $15 \mathrm{~min}$ at $4^{\circ} \mathrm{C}$ to harvest plasma. A portion of plasma was transferred to pyrogen-free glass tubes and stored at $-20^{\circ} \mathrm{C}$ for LPS analysis. The second portion of plasma was acidified and used for thiamine determination by HPLC method as introduced above in feedstuff's thiamine determination. The rest of the plasma was divided into 1-mL aliquots and stored at $-20^{\circ} \mathrm{C}$ until analysis for inflammatory cytokines.
The concentrations of LPS in plasma were determined by a chromogenic end-point LAL assay (Chinese Horseshoe Crab Reagent Manufactory Co. Ltd.) with a minimum detection limit of $0.1 \mathrm{EU} / \mathrm{mL}$. Plasma samples were initially treated as described by Khafipour et al. (2009). Briefly, frozen plasma samples were thawed at $37^{\circ} \mathrm{C}$, vortexed, and $100 \mu \mathrm{L}$ of each sample were diluted 10-fold with Tachypleus amebocyte lysate water. Diluted samples were incubated at $37^{\circ} \mathrm{C}$ for 30 min, then heated at $75^{\circ} \mathrm{C}$ for $15 \mathrm{~min}$ and cooled to room temperature $\left(19^{\circ} \mathrm{C}\right)$ for $45 \mathrm{~min}$. All samples were tested in duplicate and the optical density values were read at $545 \mathrm{~nm}$ on a microplate reader (Multiskan MK3, Thermo Labsystems).

The concentrations of LPS binding protein $(\mathbf{L B P}$; MBS705912, detection range, 15.6 to $1,000 \mathrm{ng} / \mathrm{mL}$; sensitivity $<3.9 \mathrm{ng} / \mathrm{mL}$; CV $<8 \%$ ), IL $1 \beta$ (IL1B; MBS284741: detection range, 31.25 to $2,000 \mathrm{pg} / \mathrm{mL}$; sensitivity, $15.6 \mathrm{pg} / \mathrm{mL}$; CV <8\%), IL6 (MBS038658: detection range, 15.6 to $500 \mathrm{ng} / \mathrm{mL}$; sensitivity $<2.0$ ng/mL; CV <15\%), IL10 (MBS703712: detection range, 5 to $1,000 \mathrm{pg} / \mathrm{mL}$; sensitivity, $2.5 \mathrm{pg} / \mathrm{mL}$; CV $<15 \%$ ),

Table 1. Ingredient and chemical composition of the experimental diets ${ }^{1}$

\begin{tabular}{|c|c|c|}
\hline Item & $\mathrm{CON}$ & $\mathrm{HG}$ \\
\hline \multicolumn{3}{|l|}{ Ingredient (\% of DM) } \\
\hline Chinese wildrye & 11.0 & 5.0 \\
\hline Corn silage & 34.0 & 15.0 \\
\hline Alfalfa hay & 15.0 & 15.0 \\
\hline Ground corn & 10.0 & 35.0 \\
\hline Soybean meal, $43 \% \mathrm{CP}$ & 14.0 & 14.0 \\
\hline Cottonseed meal & 5.0 & 5.0 \\
\hline Distillers dried grains with solubles & 5.0 & 5.0 \\
\hline Whole cottonseed & 3.0 & 3.0 \\
\hline Limestone meal & 1.0 & 1.0 \\
\hline Calcium hydrogen phosphate & 0.7 & 0.7 \\
\hline Sodium chloride & 0.5 & 0.5 \\
\hline Premix $^{2}$ & 0.8 & 0.8 \\
\hline \multicolumn{3}{|c|}{ Nutrient composition (\% of DM unless otherwise indicated) } \\
\hline DM (\%) & 46.87 & 50.53 \\
\hline $\mathrm{NE}_{\mathrm{L}}^{3}($ Mcal $/ \mathrm{kg})$ & 1.6 & 1.7 \\
\hline $\mathrm{CP}$ & 18.2 & 18.0 \\
\hline Starch & 20.0 & 33.2 \\
\hline $\mathrm{NDF}$ & 36.2 & 25.8 \\
\hline $\mathrm{ADF}$ & 23.4 & 17.7 \\
\hline $\mathrm{NFC}^{4}$ & 34.6 & 46.5 \\
\hline Ether extract & 4.6 & 4.1 \\
\hline Ash & 6.5 & 5.6 \\
\hline Calcium & 0.88 & 0.84 \\
\hline Phosphorus & 0.55 & 0.55 \\
\hline Thiamine $(\mathrm{mg} / \mathrm{kg})$ & 1.7 & 2.3 \\
\hline DMI $(\mathrm{kg} / \mathrm{d})$ & 15.8 & 16.6 \\
\hline Thiamine intake $(\mathrm{mg} / \mathrm{d})$ & 26.9 & 38.2 \\
\hline
\end{tabular}


Table 2. Primers used for quantitative real-time PCR analysis

\begin{tabular}{|c|c|c|c|c|c|}
\hline Gene $^{1}$ & Forward primer $\left(5^{\prime} \rightarrow 3^{\prime}\right)$ & Reverse primer $\left(5^{\prime} \rightarrow 3^{\prime}\right)$ & $\begin{array}{l}\text { Product } \\
\text { size (bp) }\end{array}$ & $\begin{array}{l}\text { Accession } \\
\text { number }\end{array}$ & $\begin{array}{l}\text { Amplification } \\
\text { efficiency (\%) }\end{array}$ \\
\hline$\overline{A C T B}$ & CCTGCGGCATTCACGAAACTAC & ACTCCTGCTTGCTGATCCACATC & 273 & NM_173979.3 & 100.60 \\
\hline$L B P$ & GGTTCCGAAGGGTCTTGGAG & CAGCATTTGGGCTGTTGCTT & 167 & NM_001038674.2 & 96.45 \\
\hline$N F \kappa B I A$ & TGAAGTGTGGGGCTGATGTC & CGGCAGTGTCTGAAGGTTCT & 134 & NM_001045868.1 & 104.80 \\
\hline$N F \kappa B$ & ATACGTCGGCCGTGTCTAT & GGAACTGTGATCCGTGTAG & 129 & NM_001076409.1 & 97.08 \\
\hline$I L 1 B$ & CCTCCGACGAGTTTCTGTGT & AAAGCTCATGCAGAACACCA & 161 & NM_174093.1 & 96.10 \\
\hline IL10 & GTGATGCCACAGGCTGAGAAC & GAAGATGTCAAACTCACTCATG & 213 & NM_174088.1 & 95.11 \\
\hline SLC19A2 & AGCAGCCAGTTGACTATACCTT & CATGTGCTGCCTAATTGCTCT & 167 & NM_001206010.1 & 98.61 \\
\hline SLC19A3 & CTCCATGATGAGACCCTC & GCAGTAGTGCCAGGTAAG & 128 & NM_001102198.1 & 97.75 \\
\hline$S L C 25 A 19$ & GTTCTCACCATTACCGTGTCC & AAGCCTTGACTGCCAGACACC & 119 & NM_001045887.1 & 102.96 \\
\hline
\end{tabular}

${ }^{1} A C T B=\beta$-actin; $L B P=$ LPS binding protein; $T L R 4=$ toll-like receptor $4 ; N F \kappa B I A=$ nuclear factor kappa B inhibitor $\alpha ; N F \kappa B=$ nuclear factor kappa $B ; I L 1 B=$ interleukin $1 \beta ; T N F \alpha=$ tumor necrosis factor $\alpha ; S L C 19 A 2=$ solute carrier family 19 , member $2 ; S L C 19 A 3=$ solute carrier family 19, member 3;SLC25A19= solute carrier family 25 member 19.

and tumor necrosis factor $\alpha$ (TNF $\alpha$; MBS033373, detection range, 15.6 to $500 \mathrm{ng} / \mathrm{mL}$; sensitivity $<2.0 \mathrm{ng} /$ $\mathrm{mL} ; \mathrm{CV}<15 \%)$ in plasma were determined by commercially available bovine ELISA kits (MyBioSource Inc., San Diego, CA) according to the manufacturer's instructions. All samples including the standards were tested in duplicate, and the optical density values were read at $450 \mathrm{~nm}$ by a microplate reader (Multiskan MK3, Thermo Labsystems).

\section{Rumen Papillae Biopsies}

On d 21 of each period, after morning feeding, rumen papillae were biopsied from the ruminal ventral sac based on the methodology developed by Steele et al. (2011). In brief, the reticulorumen contents were partially evacuated to facilitate the retraction of the ventral sac. Rumen papillae were excised (300 mg) using surgical scissors from previously unbiopsied sites, washed 20 times in ice-cold PBS ( $\mathrm{pH} 7.4$ ), snap-frozen in liquid nitrogen, and then stored at $-80^{\circ} \mathrm{C}$ until RNA isolation and protein extraction.

\section{RNA Extraction, Reverse Transcription, and Real-Time PCR}

Total RNA was isolated from approximately $100 \mathrm{mg}$ of rumen papilla using RNAiso Plus Kit (TaKaRa, Dalian, China) according to the manufacturer's instructions (http://www.takara.com.cn/DownLoad/9108Q. pdf) followed by DNase I treatment. Total RNA was quantified using a Nanodrop 1000 spectrophotometer (Nanodrop, Wilmington, DE) and RNA integrity was measured on an Agilent 2100 Bioanalyzer (Agilent, Santa Clara, CA). The average RNA integrity number of samples used was $8.3 \pm 0.8$ (mean $\pm \mathrm{SD}$ ), indicating the RNA was intact and sufficient for real- time reverse-transcription PCR analysis. The RNA samples were reverse transcribed using a PrimeScript RT reagent Kit (D6110A, TaKaRa) according to the manufacturer's instructions (https://wenku.baidu. com/view/753c15c06137ee06eff9183c.html). Primers for target and internal reference gene (ACTB) were designed with Primer Premier 5.0 and were synthesized by Invitrogen Life Technologies (Shanghai, China). The information of primers was displayed in Table 2. The real-time PCR was performed with a LightCycler 96 Real-Time PCR System (Roche Diagnostics, Mannheim, Germany) using SYBR Premix Ex Taq II Kit (DRR081A, TaKaRa). Amplification conditions were as follows: $95^{\circ} \mathrm{C}$ for $30 \mathrm{~s}$, followed by 40 cycles composed of $5 \mathrm{~s}$ at $95^{\circ} \mathrm{C}$ and $20 \mathrm{~s}$ at $60^{\circ} \mathrm{C}$. All measurements were performed in triplicate. Relative gene expression for each cow was calculated using the $2^{-\Delta \Delta \mathrm{Ct}}$ (where $\mathrm{Ct}=$ cycle threshold) method (Pfaffl, 2001), and gene mRNA levels were expressed as the fold change relative to the mean value of the control group.

\section{Protein Isolation and Western Blotting Analysis}

Rumen papilla samples ( $150 \mathrm{mg})$ were ground in liquid nitrogen and pyrolyzed with RIPA lysis buffer (P0013B, Beyotime Biotechnology, Shanghai, China). Tissue lysates were centrifuged at $12,000 \times g$ at $4^{\circ} \mathrm{C}$ for $10 \mathrm{~min}$ and the supernatant was harvested. Protein concentrations were determined in duplicate by the BCA Protein Assay Kit (P0009, Beyotime Biotechnology).

The protein samples were denatured at $100^{\circ} \mathrm{C}$ for 5 min, and then samples and marker were subjected to $12 \%$ SDS-PAGE at $60 \mathrm{~V}$ for $30 \mathrm{~min}$, then $100 \mathrm{~V}$ for $2 \mathrm{~h}$. After that, proteins were transferred to polyvinylidene difluoride membranes (Millipore Corp., Bedford, MA) using a Bio-Rad Trans-Blot apparatus $\left(4^{\circ} \mathrm{C}, 100 \mathrm{~V}\right.$, 
1.5 h; Bio-Rad, Hercules, CA). The membranes were blocked with 5\% BSA dissolved in Tris-buffered saline Tween-20 (TBST; $20 \mathrm{~m} M$ Tris, pH 7.6, $136 \mathrm{~m} M \mathrm{NaCl}$, $0.1 \%$ Tween 20 ) for $1 \mathrm{~h}$ at room temperature and subsequently incubated with the following primary antibodies in dilution buffer overnight at $4^{\circ} \mathrm{C}$ : m-anti-TLR4 (1:200; sc-293072, Santa Cruz Biotechnology, Santa Cruz, CA), rb-anti-NFkB p65 (1:500; AN365, Beyotime Biotechnology), rb-anti-NFkB phospho-p65 (ser536; 1:500; AN371, Beyotime Biotechnology), rb-anti-IL1B (1:200; sc-7884, Santa Cruz), rb-anti-IL6 (1:200; sc1265, Santa Cruz Biotechnology), rb-anti-TNFa (1:200; sc-8301, Santa Cruz), and rb-anti- $\beta$-actin (1:500; sc130656, Santa Cruz Biotechnology). $\beta$-Actin was used as a reference protein for normalization by Western blotting. After washing step with TBST, membranes were incubated with HRP-conjugated secondary antibodies (Beyotime Biotechnology, number A0208) for 1 $\mathrm{h}$ at room temperature. Protein bands were visualized using an enhanced chemiluminescence Western blotting kit (ECL-plus; GE Healthcare, Piscataway, NJ). The images were captured by a FluorChem HD2 (Protein Simple, San Jose, CA) and converted to gray values using Image-Pro Plus 6.0 (Media Cybernetics Inc., Rockville, MD) software. The protein value was presented as fold change relative to the average value of the $\mathrm{CON}$ group's protein.

\section{Statistical Analysis}

The Shapiro-Wilk and Levene tests were used to test for normality and homogeneity of variances, respectively. Data except ruminal LPS were normally distributed and homogeneous, and ruminal LPS data were log-transformed.

Data were analyzed as a replicated $3 \times 3$ Latin square design using PROC MIXED of SAS version 9.3 (SAS Institute Inc., Cary, NC). The statistical model for the trial was as follows:

$$
\begin{aligned}
Y_{i j k l m}= & \mu+T_{i}+P_{j}+S_{k}+C_{l}\left(S_{k}\right)+O_{m} \\
& +T_{i} \times P_{j}+T_{i} \times S_{k}+e_{i j k l m},
\end{aligned}
$$

where $Y_{i j k l m}$ is the dependent variable, $\mu$ is the overall mean, $T_{i}$ is the fixed effect of treatment $(i=1-3) . P_{j}$ is the fixed effect of period $(j=1-3) ; S_{k}$ is the random effect of Latin square $(k=1-2) ; C_{l}\left(S_{k}\right)$ is the random effect of cow nested in square $(l=1-6) ; O_{m}$ is the fixed carryover effect from the previous period $(O=0$ if pe$\operatorname{riod}=1) ; T_{i} \times P_{j}$ is the interaction of treatment and period, $T_{i} \times S_{k}$ is the interaction between treatment and Latin square replicate, and $e_{i j k l m}$ is the random residual error. In these analyses, the carryover effects, and the interactions between treatment and period or square were not detected for all variables, and they were finally removed from the model. The model for mean ruminal $\mathrm{pH}$ was augmented with sampling time point and time point $\times$ treatment interaction for repeated measurements.

To study the relationships between thiamine in ruminal fluid and blood, regression (Proc Reg of SAS) and correlation (Proc Corr of SAS) analyses were done. Significance was declared at $P \leq 0.05$, a tendency was considered at $0.05<P<0.10$ in this study.

\section{RESULTS}

\section{Milk Yields and Milk Composition}

As shown in Table 3, HG feeding significantly increased the milk yield and milk lactose yield $(P<$ $0.05)$, and decreased milk fat percentage and milk protein percentage $(P<0.05)$. However, milk fat yield and milk protein yield were not affected by dietary grain levels $(P>0.05)$. Thiamine supplementation increased the percentage and yield of milk fat and milk protein compared with HG-fed cows $(P<0.05)$.

Table 3. Milk yield and compositions of dairy cows fed a control diet $(\mathrm{CON})$ or high-grain diet with $(\mathrm{HG}+\mathrm{T})$ or without (HG) thiamine supplementation

\begin{tabular}{lccccc}
\hline & \multicolumn{3}{c}{ Dietary treatment } & & \\
\cline { 2 - 4 } Item & CON & HG & HG+T & SEM & $P$-value \\
\hline Milk yield (kg/d) & $17.9^{\mathrm{b}}$ & $20.2^{\mathrm{a}}$ & $21.1^{\mathrm{a}}$ & 0.42 & 0.028 \\
Milk component (\%) & & & & & \\
Fat & $4.28^{\mathrm{a}}$ & $3.83^{\mathrm{b}}$ & $4.12^{\mathrm{a}}$ & 0.10 & 0.046 \\
Protein & $3.38^{\mathrm{a}}$ & $3.11^{\mathrm{b}}$ & $3.42^{\mathrm{a}}$ & 0.04 & 0.017 \\
Lactose & 4.95 & 4.94 & 4.95 & 0.06 & 0.99 \\
Yield (kg/d) & & & & & 0.03 \\
Fat & $0.76^{\mathrm{b}}$ & $0.77^{\mathrm{b}}$ & $0.87^{\mathrm{a}}$ & 0.03 & 0.045 \\
Protein & $0.60^{\mathrm{b}}$ & $0.63^{\mathrm{b}}$ & $0.72^{\mathrm{a}}$ & 0.02 & 0.032 \\
Lactose & $0.89^{\mathrm{b}}$ & $1.00^{\mathrm{a}}$ & $1.05^{\mathrm{a}}$ & 0.02 & 0.011 \\
\hline
\end{tabular}

${ }^{\mathrm{a}, \mathrm{b}}$ Means within a row with different superscripts are different $(P<0.05)$. 


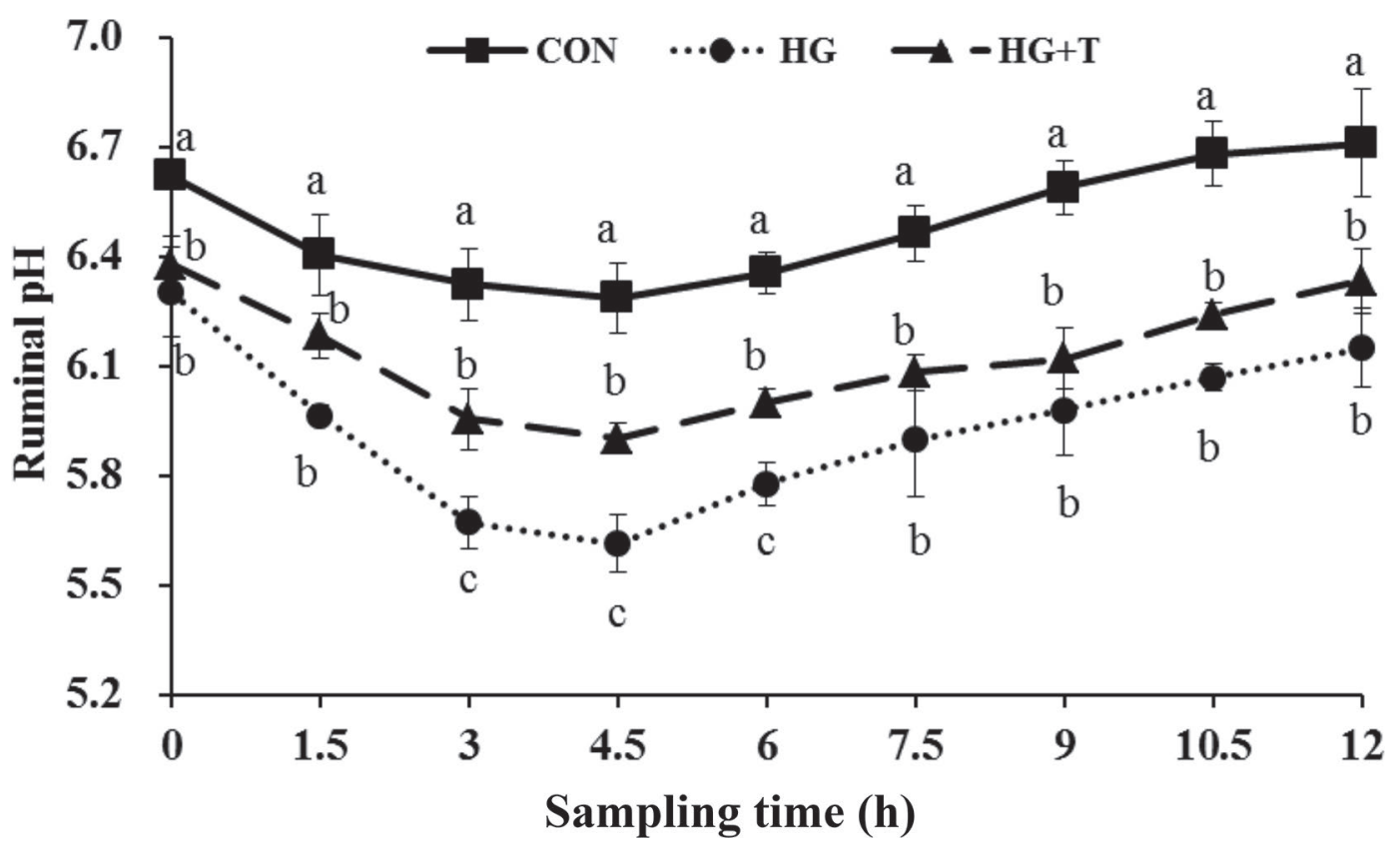

Figure 1. Ruminal $\mathrm{pH}$ values for cows fed the control diet (CON), high-grain (HG) diet, and HG diet supplemented with $180 \mathrm{mg}$ of thiamine/kg of DMI $(\mathrm{HG}+\mathrm{T})$. Data are expressed as means \pm SEM. Means with different letters $(\mathrm{a}-\mathrm{c})$ are significantly different $(P<0.05)$ at a particular sampling time point.

\section{Ruminal pH, LPS Content, and Inflammatory Cytokines}

The variation of ruminal $\mathrm{pH}$ of cows fed different diets was given in Figure 1. Ruminal pH in HG-fed cows was lower than the CON group from 0 to $12 \mathrm{~h}$ after morning feeding $(P<0.05)$, and $\mathrm{pH}$ was below 5.8 from 3 to $6 \mathrm{~h}$ in a 12-h period. Compared with HG-fed cows, cows in the $\mathrm{HG}+\mathrm{T}$ group had higher mean ruminal $\mathrm{pH}$ (Table 4 ) and ruminal $\mathrm{pH}$ at $3,4.5$, and $6 \mathrm{~h}$ postfeeding (Figure 1).

The HG feeding increased free LPS in rumen fluid from 11,815 to $134,380 \mathrm{EU} / \mathrm{mL}(P<0.05)$, and the concentration of free LPS in the rumen was reduced by thiamine supplementation $(P<0.05$; Table 4$)$. Cows fed a high-grain diet had higher concentrations of LBP

Table 4. Rumen $\mathrm{pH}$, thiamine, LPS, and inflammatory cytokine content in the rumen and plasma of dairy cows fed a control diet $(\mathrm{CON})$ or high-grain diet with $(\mathrm{HG}+\mathrm{T})$ or without $(\mathrm{HG})$ thiamine supplementation

\begin{tabular}{|c|c|c|c|c|c|}
\hline \multirow[b]{2}{*}{ Item $^{1}$} & \multicolumn{3}{|c|}{ Dietary treatment } & \multirow[b]{2}{*}{ SEM } & \multirow[b]{2}{*}{$P$-value } \\
\hline & $\mathrm{CON}$ & $\mathrm{HG}$ & $\mathrm{HG}+\mathrm{T}$ & & \\
\hline \multicolumn{6}{|l|}{ Ruminal fluid variable } \\
\hline Mean ruminal $\mathrm{pH}^{2}$ & $6.49^{\mathrm{a}}$ & $5.93^{\mathrm{c}}$ & $6.15^{\mathrm{b}}$ & 0.03 & $<0.001$ \\
\hline Thiamine $(\mu \mathrm{g} / \mathrm{L})$ & $8.97^{\mathrm{a}}$ & $2.89^{\mathrm{c}}$ & $4.81^{\mathrm{b}}$ & 0.34 & $<0.001$ \\
\hline $\operatorname{LPS}\left(\mathrm{EU}^{3} / \mathrm{mL}\right)$ & $11,815^{\mathrm{b}}$ & $134,380^{\mathrm{a}}$ & $49,361^{\mathrm{b}}$ & 2,012 & $<0.001$ \\
\hline \multicolumn{6}{|l|}{ Plasma variable } \\
\hline Thiamine $(\mu \mathrm{g} / \mathrm{L})$ & $17.63^{\mathrm{a}}$ & $11.66^{\mathrm{b}}$ & $13.75^{\mathrm{b}}$ & 0.61 & 0.003 \\
\hline LPS $(\mathrm{EU} / \mathrm{mL})$ & 0.35 & 0.38 & 0.36 & 0.14 & 0.99 \\
\hline $\mathrm{LBP}(\mu \mathrm{g} / \mathrm{mL})$ & $32.56^{\mathrm{b}}$ & $40.46^{\mathrm{a}}$ & $35.21^{\mathrm{b}}$ & 0.98 & $<0.001$ \\
\hline TNFo (ng/L) & 28.53 & 38.69 & 27.84 & 6.04 & 0.36 \\
\hline $\operatorname{IL1B}(\mathrm{ng} / \mathrm{L})$ & $104.22^{\mathrm{b}}$ & $159.08^{\mathrm{a}}$ & $133.78^{\mathrm{a}}$ & 12.39 & 0.007 \\
\hline IL6 (ng/L) & $45.36^{\mathrm{b}}$ & $54.62^{\mathrm{a}}$ & $41.11^{\mathrm{b}}$ & 4.42 & 0.041 \\
\hline IL10 (ng/L) & 14.85 & 21.75 & 22.81 & 3.79 & 0.13 \\
\hline
\end{tabular}

${ }^{\mathrm{a}-c}$ Means within a row with different superscripts are different $(P<0.05)$.

${ }^{1} \mathrm{LBP}=\mathrm{LPS}$ binding protein $\mathrm{TNF} \alpha=$ tumor necrosis factor $\alpha$; IL1B $=$ interleukin $1 \beta$.

${ }^{2}$ Mean ruminal $\mathrm{pH}$ was affected by repeated effect of daily sampling hours $(P<0.001)$, but not by interaction between treatment and sampling hour $(P=0.33)$.

${ }^{3} \mathrm{EU}=$ endotoxin unit. 


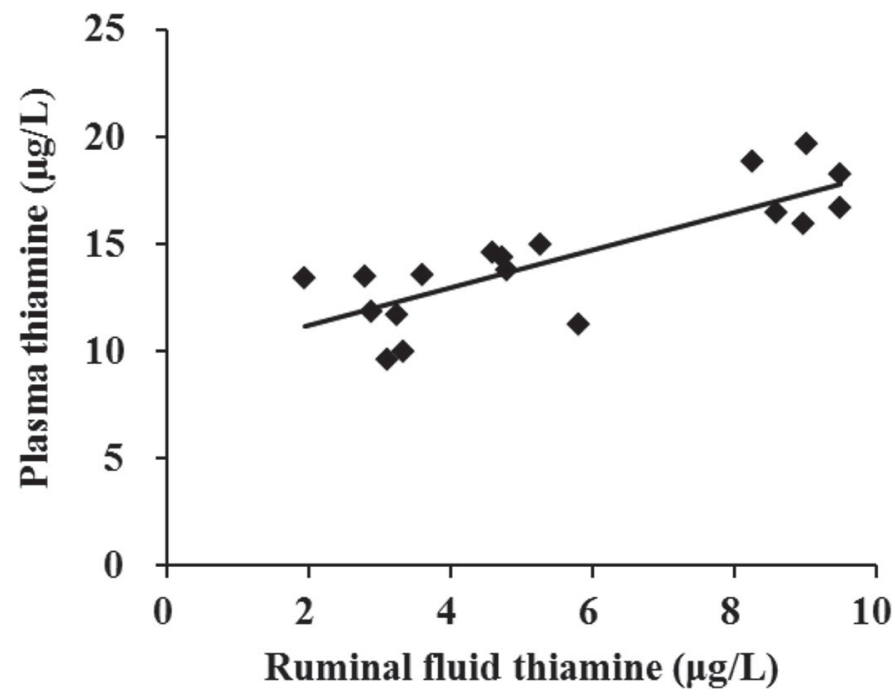

Figure 2. Linear regression of plasma thiamine concentrations (expressed as $\mathrm{Y}$ ) and ruminal fluid thiamine concentrations (expressed as $\mathrm{X})$ in dairy cows. $\mathrm{Y}=0.89 \mathrm{X}+9.42\left(\mathrm{R}^{2}=0.66, \mathrm{SE}=1.74, P<\right.$ $0.001, \mathrm{n}=18$.

and pro-inflammatory cytokines IL1B, and IL6 in peripheral blood $(P<0.05)$ than cows fed the CON diet, whereas plasma LBP and IL6 were decreased, and IL10 was increased when thiamine was provided (Table 4).

\section{Thiamine Contents in Ruminal Fluid and Blood, and Thiamine Transporter Expression in Rumen Epithelium}

Compared with cows in the CON group, HG feeding significantly decreased the concentrations of thiamine in ruminal fluid and blood $(P<0.05)$, and the situation above was reversed by thiamine supplementation (Table 4). Regression analysis showed that thiamine concentration in blood was correlated positively with ruminal thiamine content (Figure $2, \mathrm{R}^{2}=0.66, \mathrm{r}=$ $0.81, P<0.001)$.

Rumen epithelial mRNA levels of thiamine transporters THTR1, THTR2, and mitochondrial thiamine pyrophosphate transporter (MTPPT) are shown in Figure 3. Gene expression of THTR2 and MTPPT in HG-fed cows decreased significantly compared with CON cows $(P<0.05)$, whereas mRNA levels of THTR1 were not affected by dietary grain levels $(P>0.05)$. Thiamine supplementation increased the mRNA expression of 3 thiamine transporters $(P<0.05)$.

\section{Gene and Protein Expression of TLR4/NFKB Signaling Pathway in Rumen Epithelium}

Compared with the CON group, the mRNA expression of LBP, TLR4, inhibitory kappa B (IкBa), and

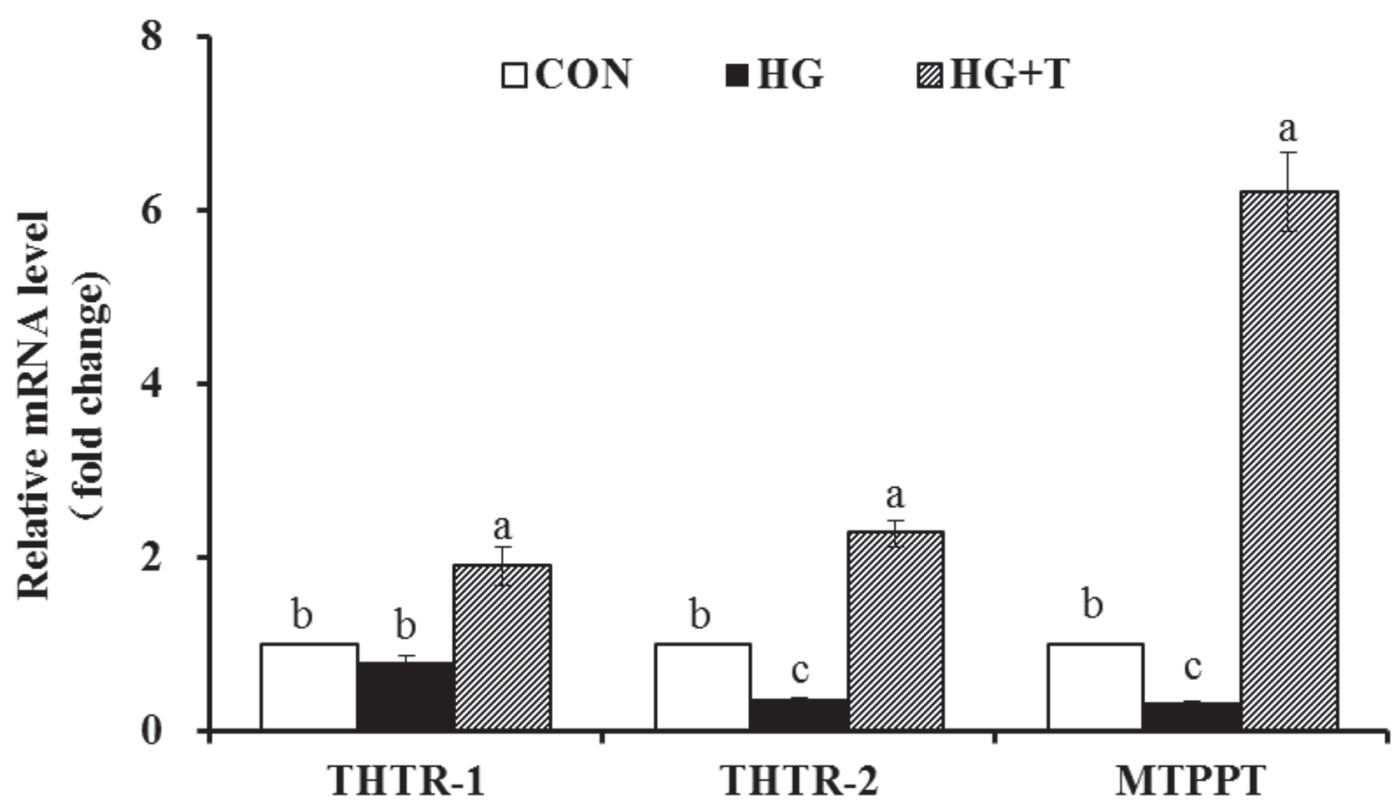

Figure 3. Effects of thiamine supplementation on relative mRNA expression of thiamine transporters in ruminal epithelium. The mRNA levels of thiamine transporters were analyzed using quantitative real-time PCR. Values are presented as means \pm SEM. Means within each transporter with different letters $(\mathrm{a}-\mathrm{c})$ are significantly different $(P<0.05)$. CON $=$ control diet; $\mathrm{HG}=$ high-grain diet; HG $+\mathrm{T}=$ high-grain diet supplemented with $180 \mathrm{mg}$ of thiamine $/ \mathrm{kg}$ of DMI. THTR-1 and THTR-2 = transporter-1 and transporter-2, respectively; MTPPT = mitochondrial thiamine pyrophosphate transporter. 
NFкB p65 were significantly upregulated in the HG group $(P<0.05)$. Western blotting analysis demonstrated that TLR4 protein expression and the phosphorylation level of NFKB p65 in rumen epithelium were upregulated in HG-fed cows $(P<0.05$; Figure 4 ), which further identify the activation of the TLR4/ NFkB signaling pathway. Corresponding to the upregulation of $\mathrm{NF} \kappa \mathrm{B}$ during $\mathrm{HG}$ diet feeding, the mRNA (Table 5) and protein (Figure 4) expression of downstream pro-inflammatory cytokines including TNFo, IL1B, and IL6 were increased $(P<0.05)$.

Compared with the HG group, HG-fed cows supplemented with thiamine had lower LBP, TLR4, I $\kappa$ Ba, and NF $\kappa$ B p65 mRNA expression $(P<0.05$, Table 5$)$, and TLR4 protein expression and the phosphorylation level of NFkB p65 (Figure 4) in the $\mathrm{HG}+\mathrm{T}$ group were downregulated $(P<0.05)$. Corresponding to the decreasing $\mathrm{NF} \kappa \mathrm{B}$ p65 phosphorylation, the protein expression of the $\mathrm{NF \kappa B}$ downstream signals including TNF $\alpha$, IL1B, and IL6 was downregulated $(P<0.05$; Figure 4).

\section{DISCUSSION}

\section{Effect of Thiamine Supplementation on $\mathrm{pH}$ and LPS Concentration in the Rumen}

Our results showed that feeding dairy cows the high-grain diet was associated with decreased $\mathrm{pH}$ and increased concentrations of LPS in the rumen fluid, which is consistent with previous studies (Khafipour et al., 2009; Plaizier et al., 2014). Concentrations of free
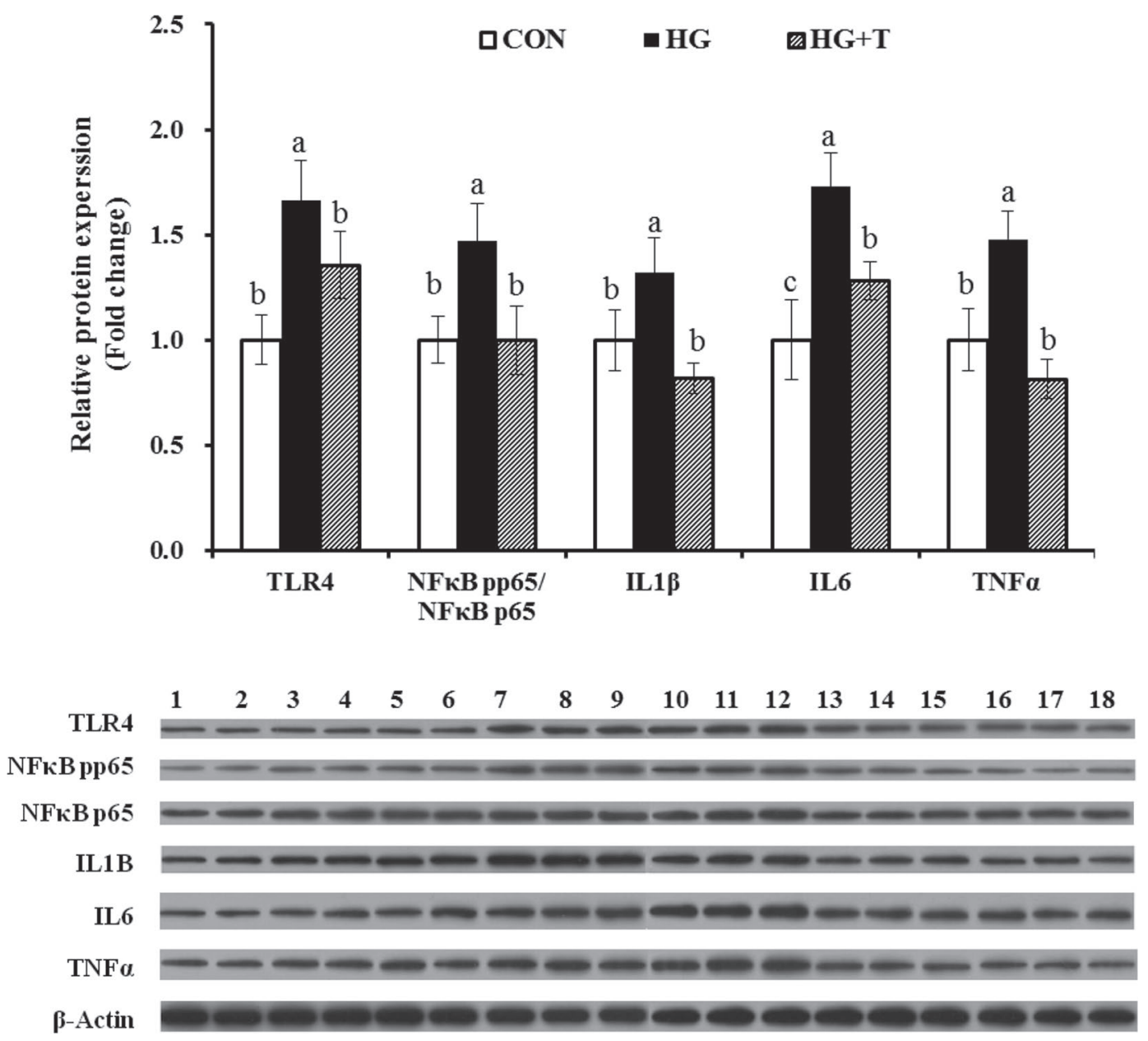

Figure 4. Protein expression of the toll-like receptor 4 (TLR4) pathways in the ruminal epithelium of dairy cows fed a low-grain diet (CON) or high-grain diet with $(\mathrm{HG}+\mathrm{T})$ or without $(\mathrm{HG})$ thiamine. The protein was quantified by band density, and $\beta$-actin was used as an internal reference. Bands 1 to 6 represent the CON group, bands 7 to 12 represent the HG group, and bands 13 to 18 represent the HG+T group. The protein value was presented as fold change relative to the average value of the protein of the CON group. Data shown are means \pm SEM. Means within each protein with different letters $(\mathrm{a}-\mathrm{c})$ are significantly different $(P<0.05)$. NFkB $=$ nuclear factor kappa $\mathrm{B}$; IL1B $=$ interleukin $1 \beta$; $\mathrm{TNF} \alpha=$ tumor necrosis factor $\alpha$. 
rumen LPS increased from 11,815 for CON to 134,380 $\mathrm{EU} / \mathrm{mL}$ for the HG group in our experiment. Similar to our results, Gozho et al. (2007) reported an LPS range of 24,547 to $128,825 \mathrm{EU} / \mathrm{mL}$ in dairy cows when the proportion of concentrate in the diet increased to $68 \%$. A recent study by Rodriguez-Lecompte et al. (2014) reported a LPS range from 10,405 EU/mL in the control to $168,391 \mathrm{EU} / \mathrm{mL}$ when the dietary starch level increased from 14.2 to $33.7 \%$. Khafipour et al. (2009) reported the ruminal LPS concentration varied from $28,184 \mathrm{EU} / \mathrm{mL}$ in the $50 \%$ concentrate diet to 107,152 / $\mathrm{mL}$ when $60 \%$ concentrate was included in the diets of dairy cows. The release of large amounts of ruminal LPS might be attributed to the increasing turnover rate of gram-negative bacteria content when cows overfeeding a high-grain diet (Plaizier et al., 2014).

Administration of thiamine increased $\mathrm{pH}$ and reduced the LPS concentrations in the rumen of HG-fed cows, and this effect could be partially due to the improvement in microbial compositions. It has been demonstrated that higher ruminal thiamine can support the protozoa population (Höltershinken et al., 2003), and thiamine supplementation significantly reduced the population of $S$. bovis and increased the population of M. elsdenii (Wang et al., 2015). Hence, the stabilized microbial structure by thiamine supplementation reduced the production of acids and eventually more stable ruminal $\mathrm{pH}$ and lower LPS from bacterial lysis. Mao et al. (2016) showed that high-grain-induced SARA increased the population of the Firmicutes phylum, and the Firmicutes phylum was positively correlated with the ruminal LPS (Lau et al., 2016). In our study, we found that the increasing population of Firmicutes during HG feeding was suppressed by thiamine supplemen-

Table 5. Quantitative real-time PCR analysis showing the effects of thiamine on toll-like receptor 4 (TLR4)-mediated nuclear factor kappa $\mathrm{B}(\mathrm{NF \kappa B})$ signaling pathway

\begin{tabular}{llllll}
\hline & \multicolumn{3}{c}{ Dietary treatment $^{2}$} & & \\
\cline { 2 - 4 } Gene $^{1}$ & CON & HG & HG+T & SEM & $P$-value \\
\hline LBP & $1.00^{\mathrm{b}}$ & $4.54^{\mathrm{a}}$ & $0.82^{\mathrm{b}}$ & 0.074 & 0.001 \\
TLR 4 & $1.00^{\mathrm{b}}$ & $4.95^{\mathrm{a}}$ & $1.57^{\mathrm{b}}$ & 0.49 & 0.002 \\
I $B$ B & $1.00^{\mathrm{b}}$ & $1.60^{\mathrm{a}}$ & $1.12^{\mathrm{b}}$ & 0.054 & 0.028 \\
NF $B$ & $1.00^{\mathrm{b}}$ & $1.78^{\mathrm{a}}$ & $0.97^{\mathrm{b}}$ & 0.15 & 0.026 \\
TNF & $1.00^{\mathrm{b}}$ & $4.02^{\mathrm{a}}$ & $2.74^{\mathrm{b}}$ & 0.25 & 0.027 \\
IL1B & $1.00^{\mathrm{c}}$ & $3.21^{\mathrm{a}}$ & $2.21^{\mathrm{b}}$ & 0.17 & 0.022 \\
IL6 & $1.00^{\mathrm{b}}$ & $4.71^{\mathrm{a}}$ & $3.50^{\mathrm{a}}$ & 0.21 & 0.012 \\
IL10 & $1.00^{\mathrm{b}}$ & $2.67^{\mathrm{b}}$ & $5.37^{\mathrm{a}}$ & 0.47 & 0.044 \\
\hline
\end{tabular}

${ }^{\mathrm{a}-\mathrm{c}}$ Means within a row with different superscripts are different $(P<$ $0.05)$.

${ }^{1} L B P=$ LPS binding protein; TLR $4=$ toll-like receptor $4 ; \operatorname{I} B a=$ inhibitory kappa B; $N F \kappa B=$ nuclear factor kappa B; $T N F \alpha=$ tumor necrosis factor $\alpha ; I L 1 B=$ interleukin $1 \beta$.

${ }^{2} \mathrm{CON}=$ control diet; $\mathrm{HG}=$ high-grain diet; $\mathrm{HG}+\mathrm{T}=$ high-grain diet supplemented with $180 \mathrm{mg}$ of thiamine/ $\mathrm{kg}$ of DMI. tation (unpublished data), and this may decrease the concentrations of free LPS in rumen digesta.

\section{Effects of HG Feeding on Thiamine Status and Transport}

In the present study, thiamine levels in CON and $\mathrm{HG}$ diets were 1.7 and $2.3 \mathrm{mg} / \mathrm{kg}$ of DM, respectively, which is similar to the values of $1.59 \mathrm{mg} / \mathrm{kg}$ in the high-fiber diet and $2.63 \mathrm{mg} / \mathrm{kg}$ in the high-starch diet reported by Beaudet et al. (2016). Santschi et al. (2005a) also reported that similar thiamine levels in a $60 \%$ forage diet $(2.27 \mathrm{mg} / \mathrm{kg})$ and a $40 \%$ forage diet $(2.64 \mathrm{mg} / \mathrm{kg})$. However, the dietary thiamine levels above were lower than those reported by Castagnino et al. (2016), varying from 2.72 to $3.58 \mathrm{mg} / \mathrm{kg}$ of DM. The deviation in thiamine content was mainly caused by the difference in dietary ingredients, because Miller et al. (1986) demonstrated that the wheat diet had a greater thiamine concentration than the corn, barley, and oat diet.

The thiamine content in rumen fluid under different dietary grain levels has been rarely reported. In the present study, the thiamine content in ruminal fluid of 3 treatments was $8.97,2.89$, and $4.81 \mu \mathrm{g} / \mathrm{L}$, respectively. However, in the study of Santschi et al. (2005b), thiamine levels ranged from 45.12 to $74.75 \mu \mathrm{g} / \mathrm{L}$, in which ruminal fluid was obtained through cannula from dairy cows, strained through 4 layers of cheesecloth, and then acidified directly. The low ruminal thiamine levels in our study may be related to the preparation of samples because the rumen fluid samples were centrifuged at $1,854 \times g$ for $10 \mathrm{~min}$ at $4^{\circ} \mathrm{C}$ to remove the feed particles before acidification. Besides, this study demonstrated that high-grain feeding decreased the ruminal thiamine content, and this may ascribed to the decreasing microbial thiamine synthesis and increasing thiamine degradation by thiaminase under low ruminal pH (Dabak and Gul, 2004).

For thiamine levels in blood, the thiamine levels in cows fed CON diet ranged from 15.9 to $19.63 \mu \mathrm{g} / \mathrm{L}$, with an mean value of $17.63 \mu \mathrm{g} / \mathrm{L}$, which is in the range of $24.85 \pm 10.1 \mu \mathrm{g} / \mathrm{L}$ (mean $\pm \mathrm{SD}$ ) reported by Olkowski et al. (1991) in beef cattle. Using dairy steers, Gooneratne et al. (1989) found that average blood thiamine concentration was $49.2 \pm 14.9 \mu \mathrm{g} / \mathrm{L}$. Hill et al. (1988) reported that a reference range of 75 to 185 $\mathrm{nmol} / \mathrm{L}(19.90-49.09 \mu \mathrm{g} / \mathrm{L})$ is proposed for cattle, and levels below $50 \mathrm{nmol} / \mathrm{L}(13.27 \mu \mathrm{g} / \mathrm{L})$ are considered indicative of deficiency. In our study, the blood thiamine levels in cows fed the HG diet $(11.66 \mu \mathrm{g} / \mathrm{L})$ were below $50 \mathrm{nmol} / \mathrm{L}$, indicating that high-grain feeding resulted in thiamine deficiency and altered thiamine status in dairy cows. The regression analysis (Figure 2) showed blood thiamine levels were positively related to rumen 
thiamine concentrations, so the inadequate microbial thiamine synthesis under SARA challenge partially contributed to the low blood thiamine (Dabak and Gul, 2004).

Another possible reason for decreasing blood thiamine levels in HG-fed cows is that thiamine absorption was reduced under high-grain feeding. The absorption of thiamine from gastrointestinal to bloodstream was mediated by carriers (Zhao and Goldman, 2013; Zhu et al., 2015). Our study observed that increasing dietary grain proportions reduced the gene expression levels of THTR2 (SLC19A3) and MTPPT (SLC25A19) in rumen epithelium. Diaz et al. (1999) have demonstrated that both THTR1 and THTR2 function as thiamine/ $\mathrm{H}^{+}$antiporters, and Arun et al. (2001) observed the transfer of thiamine is $\mathrm{pH}$ sensitive, the peak transport activity of THTR 1 and THTR2 in HeLa cells was $\mathrm{pH}$ $=7.4$ and influx at this $\mathrm{pH}$ was 3.5 -fold higher than at $\mathrm{pH}$ 5.0. Besides, LPS and pro-inflammatory cytokines could also inhibit the gene expressions of THTR1 and THTR2 (Zhu et al., 2015). In our study, the HG treatment decreased ruminal $\mathrm{pH}$ and increased LPS production in the rumen. Therefore, the transport of thiamine was inhibited and resulted in decreasing blood thiamine. However, the expression of THTR1 was not affected by dietary grain levels. The possible reason was that THTR1 is most abundant in skeletal muscle, but has low abundance in the gastrointestinal tract as demonstrated in the monogastric animal (Dutta et al., 1999; Arun et al., 2001). Additionally, researchers reported that thiamine was mainly absorbed in the intestine (Hoeller et al., 1977; Garnsworthy, 2013), and future research on whether dietary grain levels affects intestinal absorption of thiamine is needed.

In the present study, HG-fed cows administrated with thiamine supplementation had higher thiamine contents in the rumen and blood, and gene expression of THTR1, THTR2, and MTPPT in rumen epithelium was also upregulated, indicating thiamine absorption was enhanced by thiamine supplementation. The one possible reason was that thiamine improved the rumen environment by increasing $\mathrm{pH}$ and decreasing the accumulation of LPS, and hence stimulated the expression of thiamine carriers in rumen epithelium. Moreover, the active transport of thiamine by transporters is energy consuming (Hoyumpa et al., 1976), and thiamine supplementation stimulated carbohydrate metabolism and increased energy supply (Falder et al., 2010).

\section{Thiamine Attenuated Inflammatory Response}

Production and release of cytokines play a key role in inflammatory diseases. Hence, the anti-inflammatory potential of thiamine was evaluated by assessing its ef- fect on the release of several cytokines. In the present study, the gene expression of pro-inflammatory cytokines (IL1B, IL6, and TNF $\alpha$ ) in rumen epithelium was increased by HG feeding, indicating the local inflammation within rumen epithelium was triggered by the changed environmental conditions (Kleen et al., 2003). In addition, compared with CON cows, HG-fed cows had higher ruminal LPS and higher LBP and proinflammatory cytokines in blood, whereas plasma LPS content was not affected by increasing dietary grain levels. The results above can be explained in that the increased plasma LBP in HG group bound extra free LPS and subsequently was recognized by the CD14TLR4-MD2 pathway, then the activated pathway stimulated the release of pro-inflammatory cytokines (da Silva Correia et al., 2001). At the same time, we found that thiamine supplementation inversed the changes caused by HG feeding. Moreover, Yadav et al. (2010) also found that pretreatment with benfotiamine, a fat-soluble vitamin $B_{1}$ analog, in murine macrophages significantly prevented the release of these inflammatory cytokines and chemokines. This result indicated that thiamine supplementation would contribute to attenuating the inflammatory response in dairy cows, and the anti-inflammatory effects of thiamine have been demonstrated in rats (Shoeb and Ramana, 2012) and humans (Gonzalez-Ortiz et al., 2011).

\section{Possible Mechanisms for Anti-Inflammatory Effects of Thiamine}

Low ruminal $\mathrm{pH}$ has been demonstrated to lead to rumenitis and eventually to the ulceration of the ruminal epithelium (Minuti et al., 2014). When the environmental $\mathrm{pH}$ declines to the threshold level, VFA can enter the epithelium cells and acidify the cells, which results in cell necrosis (Andrews et al., 2005). In this study and our previous research (Pan et al., 2016), we both found that thiamine addition increased ruminal $\mathrm{pH}$, and the increasing ruminal $\mathrm{pH}$ may be partially responsible for the anti-inflammatory effect of thiamine supplementation.

Additionally, the effects of thiamine supplementation on local inflammation in rumen epithelium of HG-fed cows may be associated with the reduced ruminal LPS, since Gressley (2014) reported that endotoxic effects of LPS on ruminal epithelium is responsible for local inflammation under high-grain-induced SARA. At the molecular level, the increasing LPS from gram-negative bacteria was recognized by TLR4, and then NFKB was activated and translocated into the nucleus to induce the transcription of pro-inflammatory genes (Lin et al., 2008). Therefore, the inhibition of NFkB activation has been considered as a critical target and effective ap- 
proach to restrain inflammatory response (Lee et al., 2011). Concordant with previous research by Chang et al. (2015), our study showed that HG feeding augmented the phosphorylation of $\mathrm{NF} \kappa \mathrm{B}$ p65, and promoted the expression of pro-inflammatory cytokines in HG-fed cows. Nevertheless, the elevation of NFкB p65 expression was reversed when HG-fed cows were supplied with thiamine. It implied that thiamine diminished the expression of pro-inflammatory cytokines by inhibiting the activation of NFkB. Furthermore, Bozic et al. (2015) and Yadav et al. (2010) also demonstrated that benfotiamine could modulate the macrophage inflammatory response against LPS-induced inflammation by inhibiting translocation of NFKB p65 into the nucleus. Taken together, our finding indicated that thiamine exerts anti-inflammatory properties by suppressing

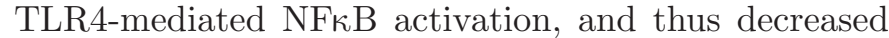
the production of pro-inflammatory cytokines including TNF $\alpha$ and IL1B.

Moreover, components of the luminal commensal microbiota play a crucial role in the mucosal immune system, and the invasion of pathogenic microorganisms and toxins can activate TLR signaling to promote the release of IL6 and TNFo that protect intestinal epithelial cells against injury (Rakoff-Nahoum et al., 2004). Chen et al. (2012) reported that the expression of TLR4 in rumen papillae was positively correlated with the copy number of total bacterial $16 \mathrm{~S}$ rRNA genes of epimural bacteria in acidosis-resistant steers. Liu et al. (2014) found the increased IL6 and IL12 mRNA expression in the high-grain-diet-fed goats was associated with the enrichment of epimural Turicibacter and Clostridium populations, which are known to have deleterious effects leading to mucosal injury. These studies above demonstrated that epithelial inflammation may be related to changes in epimural bacterial diversity and density. Manipulation of gut microbiota by feeding microbes, probiotics, or prebiotics has been widely studied in livestock animals as a strategy to improve production and health through preventing pathogen colonization (Uyeno et al., 2015; Weimer, 2015). In our study, the expression of TLR4 signaling and inflammatory cytokines in HG-fed cows decreased by thiamine supplementation, and may be partly due to the improvement in commensal microbiota and need to be verified in future research.

\section{CONCLUSIONS}

In our study, HG feeding reduced the expression of thiamine transporter 2 and mitochondrial thiamine pyrophosphate transporter in the ruminal epithelium, indicating that thiamine absorption from the ruminal epithelium in dairy cows may be inhibited by overfeed- ing a high-grain diet. We also found that thiamine supplementation could help alleviate high-grain-induced inflammation by reducing ruminal LPS and downregulating gene and protein expression of proinflammatory cytokines (TNFo, IL6, and IL1B) in ruminal epithelium. Moreover, the TLR4 protein expression and NFkB phosphorylation in HG-fed cows was suppressed by thiamine supplementation, and this may contribute to the anti-inflammatory effect of thiamine.

\section{ACKNOWLEDGMENTS}

The study was financially supported by the Project of National Nature Science Foundation of China (grant no. 31572435). We also thank the University of LiègeGembloux Agro-Bio Tech and more specifically the research platform Agriculture Is Life for funding the scientific stay in Belgium that made this paper possible.

\section{REFERENCES}

Analytical Methods Committee. 2000. Determination of thiamine and riboflavin in pet foods and animal feedingstuffs. Analyst (Lond.) 125:353-360.

Andrews, F. M., B. R. Buchanan, S. B. Elliot, N. A. Clariday, and L. H. Edwards. 2005. Gastric ulcers in horses. J. Anim. Sci. 83:18-21.

AOAC. 1990. Official Methods of Analysis, 15th ed. AOAC, Washington, DC.

AOAC International. 1995. Official Methods of Analysis, 16th ed. AOAC International, Washington, DC.

Arun, R., A. Edmondnson, I. D. Goldman, and R. Zhao. 2001. SLC19A3 encodes a second thiamine transporter ThTr2. BBA-Mol. Basis Dis. 1537:175-178.

Beaudet, V., R. Gervais, B. Graulet, P. Noziere, M. Doreau, A. Fanchone, D. D. Castagnino, and C. L. Girard. 2016. Effects of dietary nitrogen levels and carbohydrate sources on apparent ruminal synthesis of some B vitamins in dairy cows. J. Dairy Sci. 99:2730-2739.

Bozic, I., D. Savic, D. Laketa, I. Bjelobaba, I. Milenkovic, S. Pekovic, N. Nedeljkovic, and I. Lavrnja. 2015. Benfotiamine attenuates inflammatory response in LPS stimulated BV-2 microglia. PLoS One 10:e0118372.

Brent, B. E. 1976. Relationship of acidosis to other feedlot ailments. J. Anim. Sci. 43:930-935.

Breves, G., M. Brandt, H. Hoeller, and K. Rohr. 1981. Flow of thiamin to the duodenum in dairy cows fed different rations. J. Agric. Sci. 96:587-591.

Castagnino, D. S., K. L. Kammes, M. S. Allen, R. Gervais, P. Y. Chouinard, and C. L. Girard. 2016. Particle length of silages affects apparent ruminal synthesis of B vitamins in lactating dairy cows. J. Dairy Sci. 99:6229-6236.

Chang, G., S. Zhuang, H. M. Seyfert, K. Zhang, T. Xu, D. Jin, J. Guo, and X. Shen. 2015. Hepatic TLR4 signaling is activated by LPS from digestive tract during SARA, and epigenetic mechanisms contribute to enforced TLR4 expression. Oncotarget 6:38578-38590.

Chen, Y., M. Oba, and L. L. Guan. 2012. Variation of bacterial communities and expression of Toll-like receptor genes in the rumen of steers differing in susceptibility to subacute ruminal acidosis. Vet. Microbiol. 159:451-459.

da Silva Correia, J., K. Soldau, U. Christen, P. S. Tobias, and R. J. Ulevitch. 2001. Lipopolysaccharide is in close proximity to each of the proteins in its membrane receptor complex transfer from CD14 to TLR4 and MD-2. J. Biol. Chem. 276:21129-21135.

Dabak, M., and Y. Gul. 2004. Thiamine deficiency in sheep with chronic rumen acidosis. Vet. Rec. 154:58-59. 
Department of National Standards of P. R. China. 2002a. Determination of calcium in feedstuff (GB/T 6436-2002). Press of National Standards, Beijing, China.

Department of National Standards of P. R. China. 2002b. Determination of phosphorus in feedstuff (GB/T 6437-2002). Press of National Standards, Beijing, China.

Department of National Standards of P. R. China. 2002c. Determination of vitamin B1 in feedstuff (GB/T 14700-2002). Press of National Standards, Beijing, China.

Diaz, G. A., M. Banikazemi, K. Oishi, R. J. Desnick, and B. D. Gelb. 1999. Mutations in a new gene encoding a thiamine transporter cause thiamine-responsive megaloblastic anaemia syndrome. Nat. Genet. 22:309-312.

Dong, H., S. Wang, Y. Jia, Y. Ni, Y. Zhang, S. Zhuang, X. Shen, and R. Zhao. 2013. Long-term effects of subacute ruminal acidosis (SARA) on milk quality and hepatic gene expression in lactating goats fed a high-concentrate diet. PLoS One 8:e82850.

Dutta, B., W. Huang, M. Molero, R. Kekuda, F. H. Leibach, L. D. Devoe, V. Ganapathy, and P. D. Prasad. 1999. Cloning of the human thiamine transporter, a member of the folate transporter family. J. Biol. Chem. 274:31925-31929.

Emmanuel, D. G., S. M. Dunn, and B. N. Ametaj. 2008. Feeding high proportions of barley grain stimulates an inflammatory response in dairy cows. J. Dairy Sci. 91:606-614.

Emmanuel, D. G., K. L. Madsen, T. A. Churchill, S. M. Dunn, and B. N. Ametaj. 2007. Acidosis and lipopolysaccharide from Escherichia coli B:055 cause hyperpermeability of rumen and colon tissues. J. Dairy Sci. 90:5552-5557.

Falder, S., R. Silla, M. Phillips, S. Rea, R. Gurfinkel, E. Baur, A. Bartley, F. M. Wood, and M. W. Fear. 2010. Thiamine supplementation increases serum thiamine and reduces pyruvate and lactate levels in burn patients. Burns 36:261-269.

Ganapathy, V., S. B. Smith, and P. D. Prasad. 2004. SLC19: The folate/thiamine transporter family. Pflugers Arch. 447:641-646.

Garnsworthy, P. C. 2013. Nutrition and Lactation in the Dairy Cow. Butterworth, London, UK.

Gonzalez-Ortiz, M., E. Martinez-Abundis, J. A. Robles-Cervantes, V. Ramirez-Ramirez, and M. G. Ramos-Zavala. 2011. Effect of thiamine administration on metabolic profile, cytokines and inflammatory markers in drug-naive patients with type 2 diabetes. Eur. J. Nutr. 50:145-149.

Gooneratne, S. R., A. A. Olkowski, R. G. Klemmer, G. A. Kessler, and D. A. Christensen. 1989. High sulfur related thiamine deficiency in cattle: A field study. Can. Vet. J. 30:139-146.

Gozho, G. N., D. O. Krause, and J. C. Plaizier. 2007. Ruminal lipopolysaccharide concentration and inflammatory response during grain-induced subacute ruminal acidosis in dairy cows. J. Dairy Sci. $90: 856-866$

Gressley, T. F. 2014. Inflammatory responses to subacute ruminal acidosis. Pages 28-41 in 25th Annual Florida Ruminant Nutrition Symposium. University of Florida IFAS Extension, Gainesville.

Hazell, A. S., and R. F. Butterworth. 2009. Update of cell damage mechanisms in thiamine deficiency: Focus on oxidative stress, excitotoxicity and inflammation. Alcohol Alcohol. 44:141-147.

Hill, J. H., C. G. Rammell, and S. Forbes. 1988. Blood thiamine levels in normal cattle and sheep at pasture. N. Z. Vet. J. 36:49-50.

Hoeller, H., M. Fecke, and K. Schaller. 1977. Permeability to thiamin of the sheep rumen wall. J. Anim. Sci. 44:158-161.

Höltershinken, M., A. Höhling, G. Wendelken, K. Elias, and H. Scholz. 2003. Einflüsse auf den ruminalen Protozoenbesatz des Rindes (in vitro) Teil 2: Wirkung einer subklinischen Pansenazidose ohne und mit Thiaminsubstitution. Tierärztliche Praxis Großtiere. 31:178182.

Hoyumpa, A. M. J., S. Nichols, S. Schenke, and F. A. Wilson. 1976. Thiamine transport in thiamine-deficient rats: Role of the unstirred water layer. Biochim. Biophys. Acta 436:438-447.

Jhala, S. S., D. Wang, and A. S. Hazell. 2014. Thiamine deficiency results in release of soluble factors that disrupt mitochondrial membrane potential and downregulate the glutamate transporter splice-variant GLT-1b in cultured astrocytes. Biochem. Biophys. Res. Commun. 448:335-341.
Karapinar, T., M. Dabak, and O. Kizil. 2010. Thiamine status of feedlot cattle fed a high-concentrate diet. Can. Vet. J. 51:1251-1253.

Khafipour, E., D. O. Krause, and J. C. Plaizier. 2009. A grain-based subacute ruminal acidosis challenge causes translocation of lipopolysaccharide and triggers inflammation. J. Dairy Sci. 92:10601070.

Kleen, J. L., G. A. Hooijer, J. Rehage, and J. P. T. M. Noordhuizen. 2003. Subacute ruminal acidosis (SARA): A review. J. Vet. Med. A Physiol. Pathol. Clin. Med. 50:406-414.

Kurashima, Y., Y. Goto, and H. Kiyono. 2013. Mucosal innate immune cells regulate both gut homeostasis and intestinal inflammation. Eur. J. Immunol. 43:3108-3115.

Lau, E., C. Marques, D. Pestana, M. Santoalha, D. Carvalho, P. Freitas, and C. Calhau. 2016. The role of I-FABP as a biomarker of intestinal barrier dysfunction driven by gut microbiota changes in obesity. Nutr. Metab. (Lond.) 13:31-37.

Lee, K. C., H. H. Chang, Y. H. Chung, and T. Y. Lee. 2011. Andrographolide acts as an anti-inflammatory agent in LPS-stimulated RAW264.7 macrophages by inhibiting STAT3-mediated suppression of the NF-kappaB pathway. J. Ethnopharmacol. 135:678-684.

Lin, S. T., Y. Wang, Y. Xue, D. C. Feng, Y. Xu, and L. Y. Xu. 2008. Tetrandrine suppresses LPS-induced astrocyte activation via modulating IKKs-IkappaBalpha-NF-kappaB signaling pathway. Mol. Cell. Biochem. 315:41-49.

Liu, J., T. Xu, W. Zhu, and S. Mao. 2014. High-grain feeding alters caecal bacterial microbiota composition and fermentation and results in caecal mucosal injury in goats. Br. J. Nutr. 112:416-427.

Mao, S. Y., W. J. Huo, and W. Y. Zhu. 2016. Microbiome-metabolome analysis reveals unhealthy alterations in the composition and metabolism of ruminal microbiota with increasing dietary grain in a goat model. Environ. Microbiol. 18:525-541.

McDowell, L. R. 2012. Vitamins in Animal Nutrition: Comparative Aspects to Human Nutrition. Academic Press, London, UK.

Miller, B., J. Meiske, and R. Goodrich. 1986. Effects of grain source and concentrate level on B-vitamin production and absorption in steers. J. Anim. Sci. 62:473-483.

Minuti, A., S. Ahmed, E. Trevisi, F. Piccioli-Cappelli, G. Bertoni, N. Jahan, and P. Bani. 2014. Experimental acute rumen acidosis in sheep: Consequences on clinical, rumen, and gastrointestinal permeability conditions and blood chemistry. J. Anim. Sci. 92:3966-3977.

NRC. 2001. Nutrient Requirements of Dairy Cattle. 7th rev. ed. Natl. Acad. Press, Washington, DC.

Olkowski, A. A., D. A. Christensen, and C. G. Rousseaux. 1991. Association of sulfate-water and blood thiamine concentration in beef cattle: Field studies. Can. J. Anim. Sci. 71:825-832.

Pan, X. H., L. Yang, F. G. Xue, H. R. Xin, L. S. Jiang, B. H. Xiong, and Y. Beckers. 2016. Relationship between thiamine and subacute rumen acidosis induced by a high grain diet in dairy cows. J. Dairy Sci. 99:8790-8801.

Pfaffl, M. W. 2001. A new mathematical model for relative quantification in real-time RT-PCR. Nucleic Acids Res. 29:e45.

Plaizier, J. C., S. Li, M. Le Sciellour, B. L. Schurmann, P. Gorka, and G. B. Penner. 2014. Effects of duration of moderate increases in grain feeding on endotoxins in the digestive tract and acute phase proteins in peripheral blood of yearling calves. J. Dairy Sci. 97:7076-7084.

Rakoff-Nahoum, S., J. Paglino, F. Eslami-Varzaneh, S. Edberg, and R. Medzhitov. 2004. Recognition of commensal microflora by toll-like receptors is required for intestinal homeostasis. Cell 118:229-241.

Rodriguez-Lecompte, J. C., A. D. Kroeker, A. Ceballos-Marquez, S. Li, J. C. Plaizier, and D. E. Gomez. 2014. Evaluation of the systemic innate immune response and metabolic alterations of nonlactating cows with diet-induced subacute ruminal acidosis. J. Dairy Sci. 97:7777-7787.

Santschi, D. E., J. Chiquette, R. Berthiaume, R. Martineau, J. J. Matte, A. F. Mustafa, and C. L. Girard. 2005a. Effects of the forage to concentrate ratio on B-vitamin concentrations in different ruminal fractions of dairy cows. Can. J. Anim. Sci. 85:389-400.

Santschi, D. E., J. Chiquette, R. Berthiaume, J. J. Matte, A. F. Mustafa, and C. L. Girard. 2005b. Effects of methods of collection and 
sample preparation on the concentrations of B-vitamins in ruminal fluid of dairy cows. Can. J. Anim. Sci. 85:417-420.

Shoeb, M., and K. V. Ramana. 2012. Anti-inflammatory effects of benfotiamine are mediated through the regulation of the arachidonic acid pathway in macrophages. Free Radic. Biol. Med. 52:182-190.

Steele, M. A., G. Vandervoort, O. AlZahal, S. E. Hook, and J. C. Matthews. 2011. Rumen epithelial adaptation to high-grain diets involves the coordinated regulation of genes involved in cholesterol homeostasis. Physiol. Genomics 43:308-316.

Uyeno, Y., S. Shigemori, and T. Shimosato. 2015. Effect of probiotics/ prebiotics on cattle health and productivity. Microbes Environ. 30:126-132.

Van Soest, P. J., J. B. Robertson, and B. A. Lewis. 1991. Methods for dietary fiber, neutral detergent fiber, and nonstarch polysaccharides in relation to animal nutrition. J. Dairy Sci. 74:3583-3597.

Wang, D. S., R. Y. Zhang, W. Y. Zhu, and S. Y. Mao. 2013. Effects of subacute ruminal acidosis challenges on fermentation and biogenic amines in the rumen of dairy cows. Livest. Sci. 155:262-272.

Wang, H., X. Pan, C. Wang, M. Wang, and L. Yu. 2015. Effects of different dietary concentrate to forage ratio and thiamine supplementation on the rumen fermentation and ruminal bacterial community in dairy cows. Anim. Prod. 55:189-193.
Weimer, P. J. 2015. Redundancy, resilience, and host specificity of the ruminal microbiota: Implications for engineering improved ruminal fermentations. Front. Microbiol. 6:296.

Yadav, U. C., N. M. Kalariya, S. K. Srivastava, and K. V. Ramana. 2010. Protective role of benfotiamine, a fat-soluble vitamin B1 analogue, in lipopolysaccharide-induced cytotoxic signals in murine macrophages. Free Radic. Biol. Med. 48:1423-1434.

Zhang, J., M. Wang, Z. Hao, L. Yu, and H. Wang. 2014. Effects of thiamine on concentrations of volatile fatty acids and lactate in culture medium of high concentrate substrate after in vitro rumen fermentation. Chinese J. Anim. Nutr. 26:489-495.

Zhang, R., W. Zhu, and S. Mao. 2016. High-concentrate feeding upregulates the expression of inflammation-related genes in the ruminal epithelium of dairy cattle. J. Anim. Sci. Biotechnol. 7:42-55.

Zhao, R., and I. D. Goldman. 2013. Folate and thiamine transporters mediated by facilitative carriers (SLC19A1-3 and SLC46A1) and folate receptors. Mol. Aspects Med. 34:373-385.

Zhu, E., L. Fang, V. Subramanian, H. Said, and C. Sassoon. 2015 Lipopolysaccharide and cytokines inhibit thiamine uptake and thiamine transporter gene expression in C2c12 myoblasts. Am. J. Respir. Crit. Care Med. 191:4361. (Abstr.) 